\title{
PENCEGAHAN TERHADAP TINDAK PIDANA KORUPSI PEMERINTAHAN DESA: KAJIAN POLITIK KEBIJAKAN DAN HUKUM PENGELOLAAN SUMBER DAYA ALAM DESA
}

\author{
Hayat, Mar'atul Makhmudah \\ Fakultas Hukum Universitas Islam Malang, Fakultas Hukum Universitas Brawijaya Malang \\ Email: hayat.150318@gmail.com; maratulmakhmudah@gmail.com
}

\begin{abstract}
The emergence of the Law Number 6 of 2014 on Village providing the broadest space in the village to organize and manage his village in order to improve rural development and rural welfare. The village must rise and grow in the dynamic global life greater challenge. ASEAN Economic Community (AEC) is also a challenge for rural communities in competition. Rural communities should also be changed according to the demands of an increasingly global era. Infrastructure development should also continue to be made at the village level. Besides, the village required to be creative, innovative and participatory resource management in the village. Potential villages still buried in village life should be utilized for the welfare of the villagers. To manage the potential and the resources needed rural village human resources and quality management transparent and accountable, so that the potential of the village can be extracted and properly managed and optimized. This is a serious concern in the management of village resources, given the enormous potentials that exist in the village to be developed and used as a source of rural income that has not been optimized in its management. Abuses of authority and corruption at the village level are becoming increasingly vulnerable in the management of village resources. Given the central government through the Village Act already allocated funds for the village at 1 Billion - 1.4 Billion according to the needs of the village. Including the management of village resources in it. Management of village resources that are not appropriate in its implementation, will be a "hot ball" for the village government. Therefore, it is necessary for early prevention of corruption at the village level in the management of village resources to do, namely the village leadership that is transparent and accountable, improving the quality of rural human resources, information systems and the optimization of the village.
\end{abstract}

Keywords: public policy, corruption, village resources, village

\begin{abstract}
Abstrak
Munculnya Undang-Undang Desa Nomor 6 Tahun 2014 tentang Desa memberikan ruang yang seluas-luasnya kepada pemerintah desa untuk mengatur dan mengelola desanya dalam rangka meningkatkan pembangunan desa dan kesejahteraan masyarakat desa. Desa harus bangkit dan tumbuh dalam dinamika kehidupan global yang semakin besar tantangannya. Masyarakat Ekonomi ASEAN (MEA) juga menjadi tantangan tersendiri bagi masyarakat desa dalam berdaya saing. Mindset masyarakat desa harus dirubah sesuai dengan tuntutan zaman yang semakin global. Pembangunan infrastruktur juga harus terus dilakukan ditingkat desa. Disamping itu desa dituntut untuk kreatif, inovatif dan partisipatif dalam pengelolaan sumber daya desa. Potensi desa yang masih terpendam dalam kehidupan masyarakat desa harus dimanfaatkan untuk kesejahteraan masyarakat desa. Untuk mengelola potensi dan sumber daya desa dibutuhkan sumber daya manusia desa yang berkualitas dan manajemen pengelolaan yang transparan dan akuntabel, sehingga potensi-potensi desa dapat digali dan dikelola secara baik dan optimal. Hal ini menjadi perhatian serius dalam
\end{abstract}


pengelolaan sumber daya desa, mengingat besarnya potensi-potensi yang ada di desa untuk dapat dikembangkan dan dijadikan sebagai sumber pendapatan desa yang belum dioptimalkan dalam pengelolaannya. Tindakan penyalahgunaan wewenang dan korupsi ditingkat desa menjadi semakin rentan dalam pengelolaan sumber daya desa. Mengingat pemerintah pusat melalui UU Desa sudah mengalokasikan dana desa untuk sebesar 1 Miliyar - 1,4 Miliyarsesuai dengan kebutuhan desa. Termasuk pengelolaan sumber daya desa di dalamnya. Pengelolaan sumber daya desa yang tidak tepat dalam implementasinya, akan menjadi "bola panas" bagi pemerintah desa. Oleh karena itu, perlu dilakukan pencegahan dini terhadap tindak pidana korupsi di tingkat desa dalam pengelolaan sumber daya desa yang harus dilakukan, yaitu kepemimpinan desa yang transparan dan akuntabel, peningkatan kualitas sumber daya manusia desa, dan optimalisasi sistem informasi desa.

Kata kunci: kebijakan publik, tindak pidana korupsi, sumber daya desa, desa

\section{A. Pendahuluan}

Indek koruspsi indonesia tahun 2015 mengalami kenaikan yang konsisten dari tahun ke tahun. Pemberantasan korupsi terus digalakan dalam rangka meningkatkan kualitas hidup dan kesejahteraan masyarakat. Hal ini disampaikan oleh Transparency International Indonesia mengalami kenaikan 2 poin dari sebelumnya. Kenaikan itu cukup memberikan tingkat signifikansi dalam peringkatnya, yaitu 19 peringkat dari tahun sebelumnya. Saat ini indonesia urutan ke 88 dari 168 negara dengan skor 36 poin. Skor itu masih dibawah Malaysia, Singapura dan Thailand. (www.ti.or.id).

Meningkatnya indek korupsi di indonesia memberikan peluang yang cukup signifikan bagi pemerintah dan masyarakat untuk terus bekerjasama dan bergandengan tangan dalam rangka memerangi korupsi. Korupsi ini sudah menjadi "penyakit akut" di negeri ini. Dibutuhkan kerja keras dan keseriusan dalam "melawannya". Korupsi menjadi rantai yang terus melilit jiwa-jiwa yang lengah, haus akan kepentingan diri maupun golongan serta orangorang yang mengikuti hawa nafsunya belaka. Korupsi adalah kejahatan besar yang dapat menghinggapi siapa saja dalam lingkungan sekitarnya, tidak mengenal jabatan dan status sosial. Korupsi di indonesia sudah "melilitkan" akarnya diberbagai sektor serta menjadi "virus" yang terus menular.

Sejak 10 tahun terakhir, era reformasi birokrasi, perang terhadap korupsi terus dilakukan. Mulai dari tingkat ekskutif, legislatif maupun yudikatif korupsi terus diberantas. Peran Komisi Pemberantasan Korupsi (KPK) mengalami berbagai fase perjuangannya dalam menaklukan korupsi. Pemberantasan korupsi yang dilakukan oleh KPK mengalami berbagai peningkatan yang signifikan. Peran KPK dalam pemberantasan korupsi mempunyai signifikasi yang sangat kuat terhadap pola pemberantasannya. Disamping itu, sanksi dan efek 
jera bagi pelaku korupsi terus di up to date. Hal ini sebagai upaya penanganan korupsi yang lebih efektif dan efisien.

Peran KPK selanjutnya tidak harus tersentralistik berada di pusat, masyarakat menantikan KPK daerah dapat terlaksana, sehingga pemberantasan korupsi dapat lebih maksimal. Dibutuhkannya lembaga KPK di daerah adalah dalam rangka untuk membangun sinergitas yang seimbang dan berimbang dalam penanganan kasus korupsi. Hal ini penting untuk ditindaklanjuti, mengingat otonomi daearah sudah berjalan cukup baik. Keberadaan otonomi daerah adalah harus menjamin keterbukaan dan transparansi dari pemerintah daerah kepada masyarakat serta pertanggungjawabannya. Begitu juga dengan pelayanan publik menjadi akses yang paling dibutuhkan oleh masyarakat dalam menerima pelayanan. Terutama dalam penanganan tehadap tindak pidana korupsi sumber daya alam.

Indonesia Corruption Watch (ICW) dalam siaran persnya bersama FITRA dan ICEL mengungkapkan bahwa korupsi disektor sumber daya alam masih marak terjadi dibeberapa daerah, antara lain Kalimantan Barat, Kalimanatan Timur, dan Sumatera Selatan. Berbagai tindakan korupsi dilakukan misalnya penerbitan perizinan untuk pertambangan maupun alih fungsi hutan dan lain sebagainya. Dari temuan ICW tersebut, terdapat kerugian negara yang mencapai Rp. 1.92 Trilliun. (www.antikorupsi.org).

Menurut Ichwan Susanto, Eksploitasi lingkungan adalah menjadi konskuensi dari otonomi daerah yang berorientasi pada kepentingan oleh pemimpinnya. Penyokong politik kepada para pebisnis dengan mengabaikan kepentingan rakyat. Sekali gambut dikeringkan dan terbakar, sangat sulit direhabilitasi. Sekali batu bara, minyak, atau mineral logam dikeruk selamanya tidak akan kembali (Kompas, Edisi 18 Desember 2015: 6).

Diimplementasikannya Undang-Undang Desa menjadi perbincangan banyak kalangan dalam pengelolaan keuangan desa, yang di dalamnya terdapat pengelolaan sumber daya desa. Pengelolaan dana desa yang diatur dalam Undang-Undang Desa memacu kesiapan kepala desa dalam pelaksanaannya. Berbagai alasan dan faktor disampaikan oleh masyarakat terkait dengan kesiapan kepala desa dan aparatur desa, infrastruktur desa serta kepemimpinan kepala desa.

Undang-Undang Desa memberikan kewenangan secara otonom kepada pemerintah desa dalam mengelola dan mengembangkan desanya. Masyarakat desa lebih sejahtera dengan berbagai program pemberdayaan dan pengelolaan sumber daya desa. Pemerintah desa dapat melakukan pola peningkatan ekonomi desa melalui Badan Usaha Milik Desa (BUMDes), mengatur Anggaran Pendapatan dan Belanja Desa (APBDes) serta melakukan berbagai 
pembangunan infrastruktur yang dapat menunjang peningkatan ekonomi desa. Dari desa membangun negeri menjadi terwujud.

Melimpahnya sumber daya desa memberikan peluang yang signifikan bagi pemerintah desa dalam membangun perekonomian desa dan kesejahteraan bagi masyarakat desa. Potensi-potensi tersebut harus dilakukan identifikasi secara baik dan dikembangkan melalui pemberdayaan kepada masyarakat secara berkesinambungan. Banyak sekali potensi yang belum tergali secara optimal dan maksimal serta belum dikelola secara baik. Banyak kendala yang melatarbelakangi, antara lain keuangan desa, sumber daya manusia desa dan infstruktur yang tidak mendukung.

Dikucurkannya dana desa sejumlah 1 Miliyar - 1,4 Miliyar memberikan angin segar bagi desa untuk lebih maksimal dalam mengelola potensi desa dan mengembangkannya menjadi desa yang mandiri, berdaya guna dan berdaya saing tinggi mengingat Masyarakat Ekonomi ASEAN (MEA) sudah berlangsung. Ekonomi desa menjadi harapan pemerintah untuk menjadi hilir dari pembangunan ekonomi pusat.

Namun demikian, yang menjadi pertanyaan adalah bagaimana pemerintah desa melakukan pencegahan terhadap tindak pidana korupsi dalam pengelolaan sumber daya alam desa? Baik dalam pengambilan kebijakan, pengalokasian anggaran, maupun dalam pelaksanaan kebijakan. Sehingga ketakutan sebagian kalanga terhadap pelaksanaan UndangUndang Desa, terutama dalam pengelolaan sumber daya desa dapat berjalan dengan baik dan terhindar dari tindak pidana korupsi. Pencegahan terhadap tindak pidana korupsi harus terus dilakukan, sampai ke level pemerintahan yang paling rendah. Sehingga terwujudnya ekonomi masyarakat desa yang meningkat dan tatanan pemerintahan yang baik dapat terwujud. Secara otomatis reformasi birokrasi dan good government berjalan paralel berdasarkan fungsi dan kebutuhannya. Membangun negeri desa untuk kesejahteraan dan keadilan bagi seluruh rakyat indonesia.

\section{B. Pembahasan}

\section{Korupsi dan Pemerintahan Desa}

Korupsi di indonesia masih menjadi musuh besar. Pemerintah melalui KPK melakukan berbagai inisiasi untuk menumpas tindak pidana korupsi. Berbagai kasus korupsi yang dilakukan oleh beberapa oknum dengan latar belakang pendidikan dan jabatan menjadikan pelajaran yang berharga bagi seluruh lapisan masyarakat dan para pemangku kebijakan. Harus dikui bahwa korupsi adalah kejahatan besar dan merugikan negara dan rakyat. Sementara rakyat masih terkungkung dalam lembah kemiskinan dan keterpurukan, 
sementara korupsi terus merajalela. Dari semua level tingkatan korupsi seolah-olah sudah menjadi penyakit yang akut dan sulit untuk disembuhkan. Tindak pidana korupsi adalah kejahatan luar biasa yang berdampak sangat signifikan terhadap dinamika berbangsa dan bernegara. Aspek sosial, politik, budaya, dan ekonomi mempunyai dampak terhadap tindakan korupsi.

Tidak sedikit korupsi yang dilakukan oleh para pejabat publik setingkat menteri, kepala daerah provinsi atau gubernur, kepala daearah kabupaten/ kota maupun ditingkat level bawah. Padahal jika dikorelasikan dengan tingkat kesejahteraan, keluarga dan pendidikan rata-rata berada pada level yang sejahtera. Kesempatan dan peluang serta orientasi kepentingan pribadi atau kelompok yang dapat mempengaruhi perilaku korupsi.

Perilaku korupsi juga menjadi ancaman bagi aparatur desa dalam penyelenggaraan pemerintah desa. Mengingat dalam pelaksanaan Undang-Undang Desa, pemerintah desa digelontor keuangan desa sebanyak 1 milirya sampai 1, 5 miliyar setiap desa. Hal ini menjadi problem baru bagi pemerintah desa jika tidak dikelola secara baik dan benar. Pengelolaan keuangan desa dan manajemen desa harus didampingi secara serius dan berkelanjutan. Pemerintah desa dengan berbagai kekurangan dalam struktur maupun non strukturnya mengahantui dalam pelakanaannya.

Menurut Oce Madril bahwa sudah ada beberapa kasus korupsi yang menimpa pemerintah desa. Penyalahgunaan wewenang, anggaran, korupsi asset, dan pengadaan barang dan jasa. Menurutnya KPK menemukan 14 potensi persoalan dana desa yang terdiri dari 4 (empat), yaitu aspek regulasi dan kelembagaan, tata laksana, pengawasan dan sumber daya manusia. Empat aspek itu yang dapat mempengaruhi terjadinya korupsi di pemerintah desa. (www.krjogja.com).

Regulasi dan kelembagaan memberikan dampak positif terhadap percepatan pembangunan desa. Disamping itu melalui Undang-Undang Desa, desa dituntut untuk membuat lembaga Badan Kerjasama Antar Desa (BKAD) untuk mempermudah desa melakukan akses jaringan atau pengelolaan sumber daya desa secara bersama-sama, sehingga ringan sama dijinjing, berat sama dipikul menjadi slogan yang dapat diaplikasikan dalam pembangunan desa.

Di sisi lain, regulasi dan kelembagaan terdapat celah yang dapat disusupi untuk melakukan penyalahgunaan wewenang maupun tindak pidana korupsi. Besarnya potensi desa dan peluang pengelolaan sumber daya desa yang melimpah, jika kontrol terhadap pengambil kebijakan lemah mempunyai peluang yang besar untuk disalahgunakan. Partisipasi aktif masyarakat dan orientasi untuk kesejahteraan dan peningkatan ekonomi masyarakat menjadi 
tombol siren bagi pemerintah desa. Johan Budi mantan (Plt) Wakil Ketua KPK mengungkapkan bahwa rawannya tindak pidana korupsi pada tataran regulasi dan kelembagaan karena belum lengkap serta petunjuk teknis pelaksanaan keuangan desa yang juga belum lengkap menajdi celah terjadinya korupsi. (www.kpk.go.id).

Pelaksanaan tata pemerintahan desa juga mempunyai peluang terjadi korupsi desa. Pengelolaan dengan pola manajemen lama berpotensi terjadinya korpsi. Perlu dilakukan pendampingan secara berkelanjutan bagi pemerintah desa dalam mengelola tatanan pemerintahan di tingkat desa. Tidak mudah mengelola organisasi pemerintahan,dibutuhkan manajemen yang mumpuni, sistem yang baik dan sumber daya yang kompeten dan berkualitas. Oleh karena itu, investasi pendidikan bagi pemerintah desa penting dilakukan. Perekrutan aparatur desa dengan harus memperhitungkan tingkat pendidikan. Kualitas pelayanan publik, salah satu indikatornya adalah pendidikan. Kualitas pendidikan dapat berimplikasi terhadap pelayanan yang diberikan serta memberikan potensi pengembangan terhadap tata laksana pemerintahan desa untuk menjadi lebih bak, demokrtasi dan transparan.

Tata laksana menjadi hal yang terus diperbaiki. Pemerintah desa harus mengubah pola pemerintahan yang lama dengan konsep pemerintahan yang baru, yaitu melakukan reformasi birokrasi terhadap sistem pemerintahan dan aparatur sipil negara. Hal ini harus didukung oleh pengawasan yang fleksibel dan kompetitif. Pengawasan yang lemah dapat mempersubur terjadinya korupsi ditingkat desa. Pengawasan harus dilakukan secara internal maupun eksternal. Pengawasan juga perlu didukung oleh partisipasi dari masyarakat. Partisipasi yang tinggi dapat mengontrol kinrja aparatur desa dalam penyelenggaraan pemerintahan yang baik dan transparan.

Disamping itu, pengelolaan sumber daya manusia desa harus terus dilakukan berdasarkan kebutuhan dan kompetensinya. Investasi pendidikan bagi aparatur desa penting untuk meningkatkan kualitas pelayanan publik desa. Aparatur desa yang kompetitif dan berkualitas dapat berimplikasi terhadap peningkatan out put desa. Pelatihan dan pembekalan yang komprehensif dalam penataan pemerintahan bagi aparatur desa juga perlu dipertimbangkan untuk dilakukan ditingkat desa. Semakin besar pengelolaan desa atas tata aturan yang ada, semakin kompleks persoalan yang dihadapi. MEA menjadi tantangan tersendiri bagi pemerintah desa ke depan. Sumber daya manusia desa harus juga dipersiapkan secara baik dan benar. Aparatur desa adalah kunci keberhasilan pemerintahan desa.

Ada beberapa motivasi kepala desa melakukan tindak pidana korupsi, antara lain (1) kepala desa merupakan jabatan politik yang didekasikan dirinya terhadap warganya selama 24 jam. Kepala desa juga dituntut untuk dapat berpartisipasi atas kebutuhan masyarakat, mulai 
dari masyarakat yang melahirkan sampai dengan adanya kematian warganya, peran kepala desa menjadi penting kehadirannya. Otomatis dalam hal itu, kepala desa dapat sekedarnya menyumbangnya, bisa dibayangkan berapa yang harus dikeluarkan kepala desa dalam keseluruhan acara warga; (2) Karena kepala desa dipilih seara langsung oleh masyarakat berdasarkan suara terbanyak dengan modal politik yang cukup tinggi, sementara modalitas ekonomi sangat lemah, sehingga terdorong tindak pidana korupsi dilakukan untuk mengembalikan modal politik yang telah dikeluarkan selama masa pemilihan kepala desa; (3) Keberadaan kepala desa menjadi incaran partai politik untuk ditancapkan akar politiknya dengan menjadikannya kader partai politik, tidak menutup kemungkinan ruang untuk melakukan tindakan korupsi sulit dibendung, terutama ketika masa-masa pemilihan umum; (4) Lemahnya keterbukaan dan pengawasan dalam penyelenggaraan pemerintah desa menjadikan kontrol terhadap kinerja pemerintah desa tidak berjalan secara baik. Apa yang sudah direncanakan, dilaksanakan dan dianggaran tanpa diawasi secara baik, dapat berdampak terhadap terjadinya tindak pidana korupsi. (Fathur Rohman, 2011:16-17).

\section{Pengelolaan Sumber Daya Alam Desa Berdasarkan Undang-Undang Desa}

Sumber daya alam desa adalah kekayaan yang sangat melimpah bagi masyarakat desa. Setiap desa mempunyai potensi masing-masing sesuai dengan letak geografis dan karakternya. Sumber daya desa menjadi tumpuan hidup masyarakat desa. Hidup masyarakat desa dari potensi yang ada pada desa tersebut. Setiap kebutuhan masyarakat, baik perkotaan maupun perdesaan diperoleh dari potensi yang ada di desa. Sayur mayur, buah-buahan, beras maupun kebutuhan pangan bermula dari desa dan dikelola oleh masyarakat desa. Sejatinya, potensi desa sangat kaya dan berlimpah ruah, hanya saja pengelolaannya yang kurang maksimal.

Kelemahan pengelolaan sumber daya desa adalah dipengaruhi oleh minimnya pengetahuan masyarakat desa terhadap potensi yang ada, peran pemerintah dalam pengelolaan sumber daya kurang mendapat dukungan dan infrastruktur yang ada kurang mendukung dalam mendorong perekonomian desa yang berbasis pada sumber daya desa.

Disahkannya Undang-Undang Desa memberikan peluang kepada pemerintah desa dan masyarakat desa dalam mengelola sumber daya desa. Undang-Undang Desa mengamanatkan bahwa pemerintah desa diberikan kewenangan penuh untuk mengelola sumber daya desa berdasarkan pada kebutuhan dan kepentingan masyarakat. Peluang itu harus dijadikan sebagai saluran penting bagi pemerintah desa untuk melakukan terobosanterobosan dan inovasi. Harus digalakkan kreatifitas pemerintah desa dalam mengelola sumber 
daya desa dengan menjadikan desa mandiri dan berdaya saing sesuai dengan potensi yang dimilikinya. Desa akan menjadi besar jika potensi yang ada dikelola secara baik dan optimal.

Oleh karena itu, dibutuhkan pengelolaan sumber daya alam desa secara baik dan optimal. Pengelolaan sumber daya alam berbasis partisipasi masyarakat memberikan dampak ekonomi masyarakat desa yang signifikan. Perekonomian meningkat dengan tetap menjaga keletarian lingkungan. Lebih lanjut bahwa pengelolaan dalam skala kecil (skala desa) memberikan kontribusi yang positif dalam pengelolaan lingkungan dan mendukung tercapainya pembangunan berkelanjutan, secara ekonomi, sosial maupun budaya. Basis partisipasi masyarakat dalam pengelolaan sumber daya alam menjadi jembatan pengelolaan sumber daya alam dalam skala mikro namun memberikan kemanfaatan yang baik bagi masyarakat desa (Fransisca Amalia, 2013:4).

Berdasarkan Rencana Pembangunan Jangan Menengah Nasional 2015-2019 membangun indonesia dari pinggian dengan memperkuat daerah-daerah dan desa menjadi acuan dalam pengelolaan sumber daya desa. Membangun indonesia dari pinggiran adalah dengan melalui pembangunan kawasan perbatasan, pembangunan desa dan kawasan perdesaan, pengembangan tata kelola pemerintahan daerah dan otonomi daerah, penataan otonomi daerah, pengurangan overhead cos (biaya rutin) untuk dialokasikan bagi pelayanan publik dan pembangunan daerah tertinggal dan pulau-pulau terpencil. (Kementerian PPN/Bappenas, 2015).

Deputi Pengembangan Regional dan Otonomi Daerah, Kementerian PPN/Bappenas dalam sosialisasi Undang-Undang Nomor 6 Tahun 2016 tentang Desa juga mengungkapkan bahwa dalam rangka pelaksanaan Nawacita dan Trisakti (Berdaulat dalam Bidang Politik) ada 8 (delapan) prioritas utama dalam kebijakan pemberdayaan desa yang salah satu di dalamnya terdapat beberapa poin penting dalam pengelolaan sumber daya desa, antara lain menyiapkan dan menjalankan kebijakan-regulasi baru untuk membebaskan desa di kantong-kantong hutan dan perkebunan; menyiapkan dan menjalankan kebijakan-regulasi baru tentang share-holding antara pemerintah, investor dan desa dalam pengelolaan sumber daya alam; menyiapkan dan menjalankan kebijakan-regulasi baru tentang akses dan hak desa untuk mengelola sumber daya alam berskala lokal (tambang, hutan, kebun, perikanan, dan sebagainya) untuk kemakmuran rakyat; dan menjalankan program-program investasi pembangunan perdesaan (hutan, kebun, ternak, perikanan, agroindustri kerakyatan dan sebagainya) dengan pola shareholding yang melibatkan desa dan warga desa sebagai pemegang saham.

Pembangunan kawasan perdesaan sesuai dengan cita-cita pemerintah melalui NAWACITA memberikan dorongan bagi desa untuk terus berkembang dan maju. 
Pembangunan desa melalui pola pembangunan kawasan perdesaan yang mengacu kepada pembangunan sumber daya alam desa untuk kesejahteraan masyarakat desa. Sinergitas program pemerintah dengan Rencana Pembangunan Jangan Menengah Nasional menjadi kesinambungan dengan filosofi Undang-Undang Nomor 6 Tahun 2014 tentang Desa untuk meningkatkan kemandirian desa dan perekonomian desa. Kemandirian desa dan peningkatan terhadap ekonomi desa mempunyai pengaruh signifikan terhadap kesejahteraan masyarakat desa. Peningkatan ekonomi dan kemandirian desa juga dipengaruhi oleh pembangunan desa yang merata serta pengelolaan sumber daya alam desa yang optimal.

Selain dalam Nawacita dan Trisakti, arah kebijakan dan strategi pembangunan kawasan perdesaan dalam hal pengelolaan sumber daya alam desa dan lingkungan hidup berkelanjutan, serta penataan ruang kawasan perdesaan, menurut Deputi Pengembangan Regional dan Otonomi Daerah, Kementerian PPN/Bappenas (2015), ada beberapa poin penting, yaitu: (1) menjamin pelaksanaan distribsi lahan kepada desa-desa dan distribusi hak atas tanah bagi petani, buruh lahan dan nelayan; (2) menata ruang kawasan perdesaan untuk melindungi lahan pertanian dan menekan alih fungsi lahan produktif dan lahan konservatif; dan (3) merehabilitasi kawasan perdesaan yang tercemar dan terkena dampak bencana khususnya di daerah pesisir dan daerah aliran sungai.

Jelas dalam konsep pembangunan kawasan perdesaan arah kebijakan dan Rencana Pemerintah Jangka Menengah Nasional memberikan penguatan kepada pemerintah desa untuk mengelola sumber daya desa secara berkelanjutan dan optimal. Pengembangan sumber daya manusia perdesaan tentunya dengan melibatkan masyarakat desa sebagai subjek pengelolaannya. Partisipasi masyarakat desa menjadi titik kunci keberhasilan pengelolaan sumber daya desa. Kegotongroyongan dan kebersamaan masyarakat desa terus dijaga dan ditingkat untuk menjalankan program-program yang diamanatkan dalam Undang-Undang Desa.

Sementara itu, menurut Johozua M. Yoltuwu menjelaskan dalam makalahnya yang disampaikan dalam sosialisasi pelaksanaan Undang-Undang Nomor 6 Tahun 2014 tentang Desa mengemukakan, bahwa penggunaan dan pemanfaatan wilayah desa sebagai sumber daya desa adalah dalam rangka penetapan kawasan pembangunan sesuai dengan tata ruang kabupaten/kota. Arah pembangunan kawasan perdesaan sesuai dengan amanat UndangUndang Desa adalah mencakup pemenuhan kebutuhan dasar, pembangunan sarana dan prasarana desa, pengembangan potensi ekonomi lokal dan pemanfaatan sumber daya alam dan lingkungan secara berkelanjutan (Johozua M. Yoltuwu, 2015). 
Oleh karena itu, sesuai dengan Undang-Undang Desa bahwa pembangunan kawasan perdesaan menjadi bagian penting dalam pembanguann desa, termasuk di dalamnya adalah pengelolaan sumber daya alam desa. Pengelolaan sumber daya alam desa harus melibatkan peran serta masyarakat melalui pemberdayaan untuk peningkatan ekonomi masyarakat desa. Pelibatan masyarakat dalam pengelolaan sumber daya alam desa adalah dalam rangka menjamin pelaksanaannya berjalan secar maksimal dan optimal. Pembangunan desa oleh masyarakat, dari masyarakat dan untuk masyarakat yang lebih sejahtera dan mandiri.

\section{Sumber Daya Alam Desa dan Pencegahan Korupsi}

Tindak pidana korupsi bisa saja terjadi dimana-mana, kapan saja, dan oleh siapa saja. Korupsi banyak dilakukan dengan berbagai instrumen oleh pelakunya dan dengan berbagai latar belakang serta alasan yang menyertainya. Pencegahan terhadap tindak pidana korupsi merupakan bagian terpenting dalam tindakan represif dalam penanganan kasus korupsi di indonesia. Pencegahan mempunyai peran utama terhadap tindakan korupsi ke depan.

Tindakan pencegahan merupakan tindakan yang lebih halus dari tindakan represif dalam penanganan korupsi. Pencegahan merupakan bentuk pengendalian terhadap terjadinya tindak pidana korupsi. Pencegahan mempengaruhi persepsi publik terhadap tindak pidana korupsi (tipikor). Lebih lanjut dijelaskan banyak tantangan yang dihadapi dalam melakukan pencegahan terhadap tipikor.

Pertama, belum tuntasnya reformasi yang menyeluruh. Pelaksanaan reformasi birokrasi di beberapa lembaga negara mengalami berbagai kendala dan hambatan. Pemberian sanksi dan penghargaan terhadap aparatur pelayanan publik masih belum jelas, sehingga kualitas pelayanan publik masih menjadi kendala. Integritas bagi aparatur dalam pelaksanaan penyelenggaraan pemerintah masih minim ditunjukkan dengan kompetensi yang dimilikinya. Disamping itu penggajian dan kinerja belum sepenuhnya menguntungkan bagi aparatur negara dan belum tersusunnya manajemen kinerja dan standar pelayanan minimial.

Kedua, keterbukaan informasi publik yang masih belum sepenuhnya transparan yang menyangkut administrasi dan pelayanan publik. Padahal sejatinya Undang-Undang Nomor 14 Tahun 2008 tentang Keterbukaan Informasi Publik mengamanatkan bahwa keterbukaan informasi publik menjadi hak setiap warga negara yang dijamin oleh undang-undang melalui lembaga-lembaga publik. Keterbukaan informasi publik dapat mendorong kinerja pelayanan publik. Keterbukaan informasi publik sejatinya menjadi kontrol dari masyarakat terhadap lembaga-lembaga publik sesuai dengan Undang-Undang Nomor 25 Tahun 2009 Tentang Pelayanan Publik. 
Ketiga, pelaksanaan e-procurement yang belum maksimal dan menyeluruh diterapkan oleh badan publik, terutama dalam bidang layanan barang dan jasa. Keempat, partisipasi masyarakat yang terbatas serta pengawasan yang lemah terhadap pengelolaan keuangan negara baik ditingkat pusat maupun daerah. Begitu juga dengan minimnya akses terhadap pelaksanaan Anggaran Pendapatan dan Belanja Negara (APBN) maupun Anggaran Pendapatan dan Belanja Daerah (APBD). Masih sedikit lembaga publik maupun pemerintah daerah yang memberikan akses informasi terhadap pelaksanaan APBD. Hal ini dipengaruhi oleh lemahnya peran serta masyarakat dalam pelaksanaan program-program yang direncakan oleh pemerintah.

Kelima, pengaduan masyarakat yang belum dikelola secara baik, baik dalam penerimaan pelaporan masyarakat terhadap aduannya dan penanganan yang kurang maksimal menjadi kendala dalam pelaksanaan pencegahan tipikor. Prosedur dan mekanisme yang belum optimal dan sarana prasarana pengaduan yang minim. Keenam, banyaknya human interaction dengan proses perizinan yang masih belum sepenuhnya transparan dapat membuka ruang terhadap tindakan korupsi.

Dari beberapa persoalan terkait penanganan terhadap tindak pidana korupsi di atas, Harris Y. P. Sibuea memberikan pandangan yang cukup relevan dalam memaksimalkan pencegahan terhadap tindak pidana korupsi, yaitu kerjasama secara kolaboratif antara pemerintah dan pemangku kebijakan penanganan korupsi dengan wujud melakukan upaya penanaman nilai budaya integritas secara kolektif dan sistematis. Caranya adalah dengan pendidikan anti korupsi dan internalisasi budaya anti korupsi pada lingkungan publik maupun swasta. Harus mendorong terwujudnya tatanan pemerintahan yang baik dengan menyamakan persepsi bahwa korupsi itu adalah kejahatan luar biasa (Harris Y. P. Sibuea, 2014:2).

Pencegahan korupsi harus ditransformasikan kepada seluruh stakeholder pemerintahan, baik pemerintah pusat, pemerintah daerah maupun pemerintah desa sebagai ujung tombak pembangunan desa. Kasus korupsi di desa masih belum begitu besar seperti yang terjadi di tingkat pusat maupun daerah. Mengingat implementasi Undang-Undang Desa baru efektif pada tahun 2016, perlu ditingkatkan pemahaman terhadap kejahatan dan korupsi dan saknsinya kepada elemen pemerintahan desa agar mawas diri terhadap tindakan-tindakan yang mengarah kepada korupsi.

Pencegahan terhadap tindak pidana korupsi, menurut Zunaji Zamroni harus terus dilakukan dalam rangka menguatkan kapasitas pemerintah untuk kesejahteraan masyarakat. Pencegahan dapat dilakukan dari desa melalui langkah-langkah berikut. Pertama, partisipasi aktif berdesa bagi masyarakat desa. Pengetahuan bagi masyarakat desa tentang pentingnya 
pembangunan desa dan bagaimana membangun desa. Melakukan penguatan terhadap masyarakat desa dan mendidik masyarakat desa dengan tradisi berdesa. Masyarakat desa harus terus didorong dalam partisipasi aktif terhadap pembangunan desa. Mulai dari perencanaan, penganggaran, pelaksanaan dan pengawasan agar pelaksanaan pemerintahan desa tepat sasaran (Zunaji Zamroni, 2015:9).

Begitu pula pengelolaan sumber daya desa harus melibatkan masyarakat desa. Masyarakat desa harus dijadikan sebagai obyek dalam pengembangan sumber daya desa. Peran masyarakat desa dapat menggerakkan ekonomi desa. Kebersamaan dan gotong royong menjadi kunci keberhasilan pada peningkatan kesejahteraan masyarakat. Masyarakat yang sejahtera dengan potensi sumber daya alam yang melimpah yang dikelola secara optimal memberikan ruang yang luas bagi desa untuk mandiri.

Kedua, membangun demokrasi dengan mempraktikannya secara langsung dalam demokrasi lokal. Pelaksanaan musyawarah desa harus digulirkan secara demokratis, adil dan setara. Kebijakan terkait dengan hal penting tentang desa harus melibatkan masyarakat desa. Musyawarah dan mufakat harus didahulukan dalam pengambilan kebijakan. Kesamaan hak dan pendapat menjadi prioritas dalam demokrasi di tingkat lokal.

Kebijakan pengelolaan sumber daya alam desa harus memenuhi unsur berdemokrasi. Demokrasi ditingkat lokal harus dikembangkan dan diajarkan kepada masyarakat desa agar memahami pentingnya berbangsa dan bernegera. Setiap kebijakan desa yang berkaitan dengan penanganan terhadap pengelolaan sumber daya alam desa harus dilakukan secara bersamasama. Pengelolaan itu juga harus melembaga, sehingga tidak bias dalam prakteknya. Pelembagaan tata kelola sumber daya desa memberikan implikasi efektifitas dan efisiensi dalam pelaksanannya. Kebijakan dan tata kelolanya juga bersifat dinamis dan demokratis, sehingga tidak ada diskriminasi kepada suatau warga kepada warga lainnya, atau pemerintah desa kepada masyarakatnya. Pelembagaan tersebut mendidik masyarakat desa untuk bersikap adil, demokratis dan partisipatif.

Ketiga, menguatkan kontrol kepada pemerintah. Setelah memperkuat masyarakat desa dan mengembangkan kehidupan yang demokratis ditingkat desa, penting untuk dilakukan sebuah kontrol yang efisien dari warga desa kepada pemerintah desa. Pengelolaan aduan masyarakat kepada pemerintah masih lemah, terutama pada pemerintah desa. Instrumen aduan, proses aduan dan penanganan terhadap aduan masih belum jelas. Oleh karena itu, pengembangan jurnalistik tingkat desa dapat membantu masyarakat desa mengontrol kinerja pemerintah desa. 
Kontrol melalui jurnalistik desa juga dapat diterapkan terhadap kontrol pengelolaan sumber daya alam desa. Ide, gagasan, mapun saran dari masyarakat desa terhadap pengelola sumber daya alam desa dapat lebih mudah diakses dan disampaikan. Kritikan yang membangun dapat menjadi masukan bagi pemerintah desa dalam mengelola pembangunan desa. Sehingga data dan informasi yang ada dapat dihimpun oleh pemerintah desa untuk dijadikan sebagai referensi pembangunan desa yang berkelanjutan. Hal itu juga memberikan dampak positif terhadap keterbukaan informasi publik dan transparansi dalam pembangunan desa. Disamping itu, media jurnalistik menjadi ajang komunikasi yang efektif antara pemerintah dan masyarakat desa terhadap problem dan persoalan yang dihadapi, termasuk menjadi kontrol dalam pencegahan terhadap tindak pidana korupsi sumber daya alam desa.

\section{Simpulan}

Korupsi harus dipersepsikan sama bagi masyarakat dan pemerintah desa dalam rangka memutus mata rantai tindak pidana korupsi yang dilakukan oleh oknum. Kesepakatan terhadap persepsi korupsi dapat mencegah terjadinya korupsi. Mata rantai korupsi menjadi "virus" bagi lingkungan sekitar, sehingga mengakibatkan "kelumpuhan" birokrasi ketika "virus" itu menyerang. Rantai korupsi harus diputus melalui kesadaran individu dengan cara memberikan pendidikan tentang kejahatan korupsi dan implikasi yang ditimbulkan serta pemahanan terhadap sanksi yang berat bagi koruptor. Tindakan korupsi dapat terjadi dimana saja dan kapan saja serta oleh siapa saja. Oleh karena itu persepsi, pemahaman dan kesadaran terhadap kejahatan korupsi dapat memperlemah untuk melakukan tindakan korupsi.

Berdasarkan Undang-Undang Desa dengan sinergitas pembangunan pemerintah pusat melalui Nawacita dan Trisakti memberikan ruang yang cukup signifikan bagi pemerintah desa untuk melakukan berbagai kebijakan strategis terhadap potensi desanya. Tingginya potensi desa memberikan peluang menjadikan pembangunan nasional dari desa. Membangun bangsa dari desa adalah potensial terjadi. Tinggal bagaimana pemerintah desa dan masyarakat membangun desanya.

Mengingatnya banyak potensi desa yang belum dioptimalkan secara baik, maka melalui Undang-Undang Desa dan anggaran dana desa sebesar 1 miliyar - 1,5 miliyar, pemerintah desa dan masyarakat desa mempunyai peluang yang besar dalam mengelola sumber daya alam desa secara mandiri untuk kesejahteraan masyarakat desa. Pengelolaan secara transparan, akuntabel dan partisipatif adalah bagian dari pencegahan terhadap tindak pidan korupsi di desa. 


\section{Daftat Pustaka:}

\section{Buku:}

Fransisca Amalia. 2013. Pengelolaan Sumber Daya Alam Berbasis Masyarakat dalam Upaya

Konservasi Daerah Aliran Sungai: Studi Kasus Desa Keseneng Kecamatan

Sumowono Kabupaten Semarang. Program Magister Ilmu Lingkungan Program

Pascasarjana Universitas Diponegoro Semarang.

Pencegahan dan Pemberantasan Korupsi Nasional. 2012. Strategi Nasional Pencegahan dan Pemberantasan Korupsi Jangka Panjang (2012-2025) dan Jangka Menengah (20122014). Jakarta: Bappenas

\section{Peraturan:}

Undang-Undang Dasar Negara Republik Indonesia Tahun 1945

Undang-Undang Nomor 6 Tahun 2014 Tentang Desa.

\section{Jurnal:}

Fathur Rohman. 2011. Korupsi di Tingkat Desa. Jurnal Governance, Volume 2 Nomor 1 Tahun 2011. Pascasarjana Universitas Islam '45 Bekasi.

Harris Y. P. Sibuea. 2014. Pencegahan Tindak Pidana Korupsi di Indonesia. Info Singkat Hukum, Volume Vi, No. 18/II/P3DI/September/2014.

Zunaji Zamroni. 2015. Mencegah Korupsi di Desa. Review Flamma. Yogyakarta: Institute for Research and Empowerment, Edisi 45 Desember 2015.

\section{Internet:}

http://www.antikorupsi.org/id/content/negara-gagal-mengelola-sumber-daya-alam, diakses pada 29 Januari 2016.

http://www.kpk.go.id/id/berita/berita-sub/2732-potensi-korupsi-dana-desa-diakui. Senin, 15 Juni 2015, diakses pada 30 Januari 2016.

http://krjogja.com/liputan-khusus/analisis/4201/mencegah-korupsi-dana-desa.kr. 2 Oktober 2015. 09.07 WIB, diakses pada 30 Januari 2016.

https://www.ti.or.id/index.php/publication/2016/01/27/corruption-perceptions-index-2015.

Rabu 27 Januari 2016 12:10:14, diakses pada 29 Januari 2016. 


\section{Makalah:}

Deputi Pengembangan Regional dan Otonomi Daerah, Kementerian PPN/ Bappenas. 2015. Arah Kebijakan Nasional Pembangunan Desa dan Kawasan Perdesaan Dalam RPJMN 2015-2019. Disampaikan dalam acara Sosialisasi Pelaksanaan UU No. 6 Tahun 2014 tentang Desa. Jakarta 28 April 2015.

Johozua M. Yotuwu. 2015. Arah Kebijakan, Kewenangan, Tugas Pokok dan Fungsi Ditjen Pembangunan Kawasan Perdesaan. Makalah disampaikan dalam Sosialisasi Pelaksanaan UU No. 6 Tahun 2014 Tentang Desa di Jakarta, 28 April 2015.

\section{Koran:}

Ichwan Susanto. 18 Desember 2015. Momentum Bijak Mengelola Sumber Daya Alam. Kompas. 